W roku akademickim 2007/2008 członkowie Koła Naukowego Specjalistów Informacji zorganizowali Kurs Wyszukiwania Informacji, skierowany do studentów Uniwersytetu Mikołaja Kopernika w Toruniu (dalej: UMK) i mający na celu przybliżenie podstawowych strategii wyszukiwania informacji w Internecie.

Kurs został zorganizowany w dniach od 14 kwietnia do 12 maja 2008 r., a swoje uczestnictwo w nim zadeklarowało 27 studentów różnych kierunków kształcenia (socjologii, informacji naukowej i bibliotekoznawstwa, prawa, administracji, archiwistyki i zarządzania dokumentacją, ekonomii, filologii angielskiej, geografii, etnologii, zarządzania i marketingu, historii sztuki i Międzywydziałowych Indywidualnych Studiów Humanistycznych). Zajęcia odbywały się w Uczelnianym Centrum Nowoczesnych Technologii Nauczania - z wykorzystaniem platformy zdalnego nauczania Moodle - i objęły 5 cotygodniowych, półtoragodzinnych spotkań. Program kursu, przygotowany i zrealizowany przez autorki niniejszego artykułu, uwzględniał:

1. Wyszukiwanie w katalogach bibliotek:

a) katalog Biblioteki Uniwersyteckiej w Toruniu,

b) bazy danych Biblioteki Narodowej,

c) KARO,

d) NUKAT.

2. Metody i strategie wyszukiwania w Internecie:

a) strategia wyszukiwawcza (definicja, jej etapy),

\section{Kurs Wyszukiwania Informacii dla studentów Uniwersytetu Mikołaja Kopernika w Toruniu}

b) narzędzia internetowe: katalogi, wyszukiwarki, bazy danych,

c) mechanizmy ułatwiające wyszukiwanie: operatory logiczne, maskowanie, ograniczanie, stop-lista, składnia specjalna, metadane,

d) Google i inne wyszukiwarki,

e) Ukryty Internet (termin i narzędzia).

3. Specjalistyczne źródła danych w Internecie:

a) katalogi tematyczne, specjalistyczne bazy danych,

b) weblogi,

c) repozytoria cyfrowe.

4. Ocena jakości informacji elektronicznej.

Kurs poprzedzono i zakończono dwukrotnymi badaniami ankietowymi jego uczestników. Zadaniem ankiety wstępnej było rozpoznanie zwyczajów związanych $\mathrm{z}$ wyszukiwaniem informacji, ankiety podsumowującej zaś ocena przydatności kursu. W obydwu kwestionariuszach znalazły się pytania zamknięte (jedno- i wielokrotnego wyboru), otwarte i półotwarte.

Pierwsza z ankiet składała się z 42 pytań, a do jej wypełnienia przystąpiło 27 osób. Przechodząc do omówienia wyników badań, warto podkreślić, że w przypadku, gdy suma odpowiedzi jest mniejsza niż liczba ankietowanych, oznacza to, iż nie wszyscy badani udzielili odpowiedzi na dane 
pytanie. Suma odpowiedzi przekraczająca liczbę ankietowanych dowodzi z kolei, że przytaczane dane zostały uzyskane za pomocą pytania wielokrotnego wyboru.

Niemal wszyscy studenci (26 osób) zauważyli, że istnieje bardzo duże zapotrzebowanie na kursy wyszukiwania informacji. Większość badanych przyznała, że kurs taki - podobnie jak szkolenie biblioteczne powinien być obowiązkowo realizowany na studiach i trwać około 10 godzin lekcyjnych. 5 osób stwierdzi$\nmid$ ło, że istnieje potrzeba uruchomienia 30 godzin tego typu zajęć, a 2 - że aż 60. Według respondentów, w programie kursu powinny znaleźć się przede wszystkim zagadnienia związane z Internetem, wyszukiwaniem materiałów naukowych oraz użytkowaniem baz danych. 11 osób uznało, że jego zakresem mogłyby być objęte również kwestie dotyczące korzystania z materiałów drukowanych. Od tego typu kursu ankietowani oczekiwaliby głównie zaznajomienia ze strategią szybkiego i efektywnego wyszukiwania informacji w sieci Internet (12 odpowiedzi) oraz skutecznego wyszukiwania informacji w ogóle (8 odpowiedzi).

Wszyscy respondenci zgodzili się, że umiejętność wyszukiwania informacji jest w dzisiejszych czasach bardzo cenna, wymaga jednak specjalistycznego przygotowania, a tego - zdaniem aż 21 ankietowanych - brakuje obecnym pracownikom bibliotek.

Doświadczenia studentów związane z nabywaniem umiejętności wyszukiwania informacji $\mathrm{w}$ Internecie nie są imponujące. Mimo że prawie wszyscy (25 osób) uczęszczali w szkole podstawowej lub gimnazjum na zajęcia technologii informacyjnej, to wyszukiwanie informacji w programie zajęć miało jedynie 8 osób. Aż 19 studentów nie zetknęło się $\mathrm{z}$ tą tematyką na pierwszym etapie kształcenia, 8 ankietowanych poznało ją dopiero w szkole średniej (liceum). W przypadku 6 osób były to zajęcia technologii informacyjnej, w przypadku 1 - szkolenie biblioteczne.

W ramach lekcji technologii informacyjnej 15 osób poznawało zasady poruszania się w sieci Internet. Co dziwne, według relacji większości z nich, treści programowe nie obejmowały posługiwania się wyszukiwarkami internetowymi. Osoby, które odbyły lekcje z tego zakresu (6), wśród poznanych narzędzi wymieniały: Google (3 odpowiedzi), Yahoo!, Altavistę, Wirtualną Polskę, Onet (2 odpowiedzi) oraz Search.com (1 odpowiedź). Odpowiedzi udzielone na to pytanie dowiodły, że studenci mieli poważne problemy z rozróżnieniem podstawowych terminów informatycznych, zamiennie stosowali bowiem pojęcia wyszukiwarka i przeglądarka.

Podobnych problemów dostarczyły respondentom terminy odnoszące się do ekonomiki informacji. Choć do znajomości określenia wywiadownia gospodarcza przyznały się 3 osoby, żadna z nich nie potrafiła podać jej przykładu. Często były one także mylone $\mathrm{z}$ bazami firm. Tylko 8 ankietowanych potrafiło poprawnie zdefiniować zakres zadań infobrokera, utoż- 
samiając wykonywanie tego zawo$\mathrm{du} \mathrm{z}$ profesjonalnym wyszukiwaniem i odpłatnym udostępnianiem informacji. Odpowiadając na pytanie „Czy zleciłbyś wyszukiwanie potrzebnych informacji wyspecjalizowanej firmie?", 13 osób stwierdziło, że skorzystałoby z takiej możliwości. Tyle samo osób na taki krok by się nie zdecydowało. Dla 23 respondentów wpływ na tę decyzję miałaby cena takiej usługi.

W odpowiedzi na pytanie o częstotliwość poszukiwania informacji w Internecie większość badanych (21 osób) zadeklarowała, że prowadzi je codziennie. 5 osób wykonuje tę czynność kilka razy w tygodniu, a 1 osoba raz w miesiącu lub rzadziej. 25 studentów poszukuje przy tym faktów (adresów, godzin otwarcia urzędów), 27 materiałów potrzebnych do zajęć, 22 - informacji na temat bieżących wydarzeń, 14 - ofert sklepów. 2 osoby korzystają z sieci głównie ze względu na pocztę elektroniczną, a kilka z uwagi na konieczność obsługi elektronicznych kont bankowych, poszukiwanie informacji prawnych, europejskich i gospodarczych, zainteresowanie ofertami agencji nieruchomości i pracy czy w celach rozrywkowych.

Badania dowiodły, że niemal wszyscy kursanci (23 osoby) korzystali z Internetu za pomocą łącza stałego. Wśród tych osób 2 osoby dostęp taki posiadały krócej niż rok, 8 osób w przedziale 2-4 lat, 6 osób - od 5 lat, a 8 osób - od co najmniej 6 lat. Respondenci nieposiadający stałego dostępu do sieci zadeklarowali, że najczęściej korzystają z niej w kafejkach interne- towych ( 2 osoby), bibliotece (1 osoba) lub w salach dydaktycznych na uczelni (1 osoba).

W opinii ankietowanych, najpopularniejszą wyszukiwarką jest Google - wskazało ją aż 26 respondentów. Wśród innych odpowiedzi znalazły się Yahoo! (11 odpowiedzi), Altavista (6), Wirtualna Polska (4), Infoseek, MSN, Netscape (po 1 odpowiedzi). Intrygujący wydaje się fakt, że 8 osób nie potrafiło wskazać wyszukiwarki innej niż Google. 1 osoba wymieniła wyszukiwarkę plików muzycznych BearShare i wyszukiwarkę osób Wyczajka. W niektórych odpowiedziach były dodatkowo wymieniane Mozilla Firefox, Internet Explorer czy Opera, co po raz kolejny dowiodło, że studenci nie odróżniali wyszukiwarki od przeglądarki internetowej.

Na pytanie „W jaki sposób wyszukujesz informacje w Internecie? (czego używasz?)" respondenci udzielili zróżnicowanych odpowiedzi. 26 osób wskazało na wyszukiwarki (20 - Google, 1 - Altavista, 5 - bez podania konkretnej nazwy), 4 - na przeglądarki (?!). Wśród innych narzędzi studenci wymieniali: katalogi on-line bibliotek, Wikipedię, odnośniki znalezione na przeglądanych stronach internetowych, katalogi i specjalistyczne serwisy, polskie i zagraniczne portale internetowe oraz zakładki z wybranymi stronami WWW.

Odpowiadając na pytanie dotyczące sposobu wyszukiwania informacji, 21 studentów przyznało, że wpisuje do wyszukiwarki odpowiednie frazy wyszukiwawcze. 13 osób korzy- 
sta z Wikipedii i przegląda odnośniki na znalezionych stronach WWW, 4 przeszukują katalogi bibliotek on-line, 2 - penetrują źródła elektroniczne i tradycyjne. 1 osoba podkreślała wykorzystywanie katalogu bibliotecznego, a 2 - przeszukiwanie specjalistycznych (dziedzinowych) stron internetowych. Pojedynczy respondenci jako sposób pozyskiwania informacji potraktowali także przeglądanie oferty sklepów internetowych.

Co do samego procesu wyszukiwania informacji za pomocą wyszukiwarek, 13 osób stwierdziło, że wykorzystuje do tego opcje wyszukiwania zaawansowanego, a 22 osoby, że zawężają wpisywane $\mathrm{w}$ wyszukiwarkę zapytanie. Większość respondentów była także świadoma, że wyszukiwarki internetowe nie indeksują wszystkich stron WWW (16 odpowiedzi). Wśród 19 osób korzystających wyłącznie z wyszukiwarki Google, 17 choć raz skorzystało z opcji „Podobne strony”, ale tylko 9 z opcji „Kopia strony". Za najpopularniejsze narzędzia wyszukiwawcze Google zostały uznane Google Grafika (18 osób) i Google Scholar (3 osoby). Z innych wyszukiwarek specjalistycznych tylko 1 osoba wymieniła wyszukiwarkę Search.com, a 2 osoby, mimo deklaracji znajomości takich narzędzi, nie potrafiły podać ich nazwy.

Interesujące są odpowiedzi udzielone na 2 pytania dotyczące korzystania z baz danych. Mimo że 21 osób zapewniło o korzystaniu z baz danych, $7 \mathrm{z}$ nich nie potrafiło podać ani jednej ich nazwy. Pozostałe osoby najczęściej wymieniały: bazy aktów prawnych na stronie Sejmu RP, bazę prawniczą LEX, rozkład jazdy PKP, bazę statystyczną Polskie Generalne Sondaże Społeczne GUS, bazy specjalistyczne ProQuest, Cybercrime i SEZAM, bazy Ośrodka Przetwarzania Informacji w Warszawie, bazy bibliograficzne Biblioteki Narodowej oraz bazy EBSCO udostępniane z poziomu Biblioteki Uniwersyteckiej w Toruniu. By sprawdzić wiedzę respondentów o bazach danych, zapytano, czy wyszukiwarki internetowe indeksują rekordy baz danych. 2 osoby uznały, że tak, 9 uznało, że nie, a 16 osób nie potrafiło na to pytanie odpowiedzieć.

W kwestii wykorzystywania innych źródeł informacji sieciowej 18 osób zadeklarowało korzystanie z czasopism elektronicznych udostępnianych w Internecie, a 10 z legalnie publikowanych e-booków. Co najmniej za brak konsekwencji należy uznać fakt, że tylko 5 osób (!) przyznało, że wie, gdzie takich książek szukać. Wśród przykładowych źródeł udostępniających e-booki studenci wymieniali: wyszukiwarki, strony związane z Creative Commons, Google Books, SAGE Journals Online, Bibliotekę Narodową. Jedna osoba przyznała: „trafiam na nie bardzo przypadkowo”.

Na ostatnich zajęciach Kursu Wyszukiwania Informacji 21 uczestników wypełniło ankietę podsumowującą. Służyła ona poznaniu ich opinii na temat przebiegu samego kursu oraz uzyskaniu wskazówek przydatnych do prowadzenia podobnych kursów w przyszłości. Większość oceni- 
ła kurs jako spełniający ich oczekiwania: 12 osób znacznie wzbogaciło swoją wiedzę na temat wyszukiwania informacji, a 8 - ją uzupełniło. 1 osoba nie umiała ocenić przydatności kursu. Wszyscy studenci jednomyślnie potwierdzili przydatność platformy Moodle w prowadzeniu zajęć. Aż 16 z nich korzystało z tego narzędzia i z umieszczonych w nim zasobów poza godzinami kursu.

Co do samej organizacji szkolenia, studenci podkreślali, że kurs był prowadzony kompetentnie, ciekawie i zrozumiale pod względem językowym, a zajęcia odbywały się w przyjaznej atmosferze. Pojawiło się także 7 uwag krytycznych, sugerujących, że zajęcia prowadzono zbyt szybko lub zbyt wolno oraz że realizowano zbyt mało ćwiczeń praktycznych.

Niektórzy uczestnicy szkolenia wskazali także na zagadnienia, które powinny być w nim szerzej omówione. Były to przede wszystkim kwestie związane z wyszukiwaniem publikacji i czasopism naukowych, wykorzystywaniem baz danych, katalogów, repozytoriów, zasobów Ukrytego Internetu, bibliotek cyfrowych oraz stosowaniem algebry Boole'a czy języka haseł przedmiotowych KABA.

W osobnym pytaniu respondenci przyznali, że w program kursu należałoby włączyć jeszcze więcej ćwiczeń praktycznych (13 odpowiedzi). 6 osób stwierdziło, że na kursie zabrakło zadań do samodzielnego wykonania, a 2 osoby, że było zbyt mało czasu w stosunku do dużej ilości materiału. 3 osoby zauważyły, że na kursie poruszono wszystkie przydatne zagadnienia. Pojawiły się także pojedyncze propozycje dotyczące uwzględnienia $\mathrm{w}$ programie kursu zagadnień związanych z krytyką źródeł oraz wyszukiwaniem źródeł informacji dziedzinowej.

Kurs zgromadził studentów i absolwentów różnych kierunków studiów (głównie humanistycznych). Rozpiętość wieku uczestników kształtowała się w przedziale od 19 do 30 lat. Choć kurs rozpoczynała niemal jednakowa liczba kobiet (15) i mężczyzn (12), do ostatnich zajęć nie dotrwało 6 mężczyzn. Można z tego wysnuć wniosek, że uczestniczki kursu były bardziej konsekwentne, a podjęte zobowiązanie postanowiły doprowadzić do końca. Podobna zależność wystąpiła w przypadku absolwentów szkół sprzed reformy edukacji i po niej. Kurs rozpoczynało 11 absolwentów szkoły zreformowanej i 16 absolwentów szkół sprzed reformy. Na ostatnich zajęciach absolwentów zreformowanej szkoły było już tylko 6 wobec 15 absolwentów sprzed reformy edukacji. Większa wytrwałość absolwentów „starego trybu edukacji" może być związana z tym, że byli oni studentami wyższych lat studiów i mieli świadomość przydatności umiejętności, jakie można nabyć na kursie - i to nie tylko pod kątem przygotowywania np. pracy magisterskiej, ale także ich wykorzystania w życiu codziennym, np. podczas poszukiwania pracy. Niepokojące jest to, że w edukacji poprzedzającej studia uniwersyteckie zbyt rzadko ukierunkowuje się zachowania uczniów w zakresie wykorzystywania sieci Internet. 
Podsumowując, należy stwierdzić, że kursy wyszukiwania informacji na uczelniach wyższych powinny być regularnie przeprowadzane, ponieważ studenci odczuwają potrzebę uczestnictwa w tego typu inicjatywach. Może o tym świadczyć duże zainteresowanie kursem zorganizowanym przez bibliotekoznawców. Tego, że warto takie kursy przeprowadzać, dowodzi choćby brak umiejętności rozróżniania podstawowych terminów informatycznych wśród uczestników kursu czy stosowanie przez nich najprostszych metod wyszukiwawczych (wpisywanie żądanej frazy do wyszukiwarki Google).

Wydaje się, że kurs spełnił swoje zadanie, choć na początku niektórzy studenci oczekiwali podania konkretnych - dających się zastosować w każdym procesie wyszukiwania informacji sieciowej - strategii; kurs przekonał ich, że nie da się podać gotowych i niezawodnych rozwiązań, ponieważ $\mathrm{w}$ procesie wyszukiwania informa-

W dniach 14-15 maja 2009 r. odbyła się w Bydgoszczy Ogólnopolska Konferencja Naukowa „Bibliotekarz: uniwersalność i innowacyjność profesji", której organizatorami były Katedra Informacji Naukowej i Bibliologii (dalej: KINiB UKW) oraz Biblioteka Główna Uniwersytetu Kazimierza Wielkiego w Bydgoszczy (dalej: Biblioteka Główna UKW). Sesja, skierowana do ośrodków naukowych i bibliotek, w których są prowadzone badania nad współczesnym bibliotekarstwem, była poświę- cji konieczne jest samodzielne opanowanie podstawowych technik wyszukiwania oraz świadomość istnienia różnorodnych narzędzi wyszukiwawczych, z czym należy wiązać także umiejętność krytycznej oceny znalezionych informacji. Niestety, badania dowiodły, że większość użytkowników sieci nadal nie rozwinęła w sobie tej umiejętności. Potrzeba kształcenia $\mathrm{w}$ tym zakresie wydaje się więc $\mathrm{w}$ pełni uzasadniona, zwłaszcza w kontekście budowy społeczeństwa opartego na wiedzy i informacji.

\section{Paulina Łapińska, Małgorzata Stranc} absolwentki informacji naukowej i bibliotekoznawstwa Uniwersytetu Mikołaja Kopernika w Toruniu z roku 2009

\section{Marta Wontorowska}

uczestniczka studiów doktoranckich

z zakresu bibliologii, prowadzonych na Wydziale Nauk Historycznych Uniwersytetu Mikołaja Kopernika w Toruniu

\section{Ogólnopolska Konferencja Naukowa „Bibliotekarz: uniwersalność i innowacyiność profesji" (Bydgoszcz, 14-15 maja 2009 r.)}

cona zagadnieniom uniwersalności zawodu bibliotekarza w małej bibliotece, jego wizerunkowi, funkcjonującym nadal stereotypom, bibliotekarstwu dziedzinowemu, obsłudze różnych grup 